\title{
Lityum Metaborat Dihidratın Difüzyon Katsayısının Belirlenmesi
}

\author{
Mehmet Sait İZGİ, Ömer ŞAHIN, Tülin HANSU \\ Siirt Üniversitesi Mühendislik Mimarlık Fakültesi, Kimya Mühendisliği Bölümü
}

\begin{abstract}
$\ddot{O} \mathbf{z}$
Bor bileşikleri ile ilgili çalışmaların hızla çeşitlilik kazanması bu bileşiklerin endüstriyel üretim koşullarının belirlenmesinin önemini daha da artırmaktadır. Bu bağlamda bu çalışmada, kristalizasyon yöntemi kullanılarak lityum metaborat dihidrat bileşiğinin $45^{\circ} \mathrm{C}, 50^{\circ} \mathrm{C}$ ve $60^{\circ} \mathrm{C}$ sıcaklıklarındaki üretim koşullarından biri olan kristal büyümesini etkileyen difüzyon adımı ve çeşitli parametrelere bağlı olan difüzyon katsayısı belirlenmiştir. Difüzyon katsayısının belirlenmesinde diyafram hücre tekniğinden yararlanılmıştır. Ayrıca $45^{\circ} \mathrm{C}$ deki difüzyon katsayısının $50{ }^{\circ} \mathrm{C}$ de ve $60{ }^{\circ} \mathrm{C}$ dekine göre daha yüksek olduğu belirlendi. Bundan dolayı $45^{\circ} \mathrm{C}$ deki bu davranışı aydınlatmak için farklı doygunluk sıcaklıklarındaki viskozite değerleri ölçülerek difüzyon katsayıları bu eşitliğe göz önünde bulundurularak hesaplanmıştır.
\end{abstract}

Anahtar kelimeler: Lityum Metaborat Dihidrat, Difüzyon, Kristalizasyon, Diyafram Hücre.

\section{Determination of Diffusion Coefficient of Lithium Metaborate Dihydrate}

\begin{abstract}
The rapid diversification of studies on boron compounds further increases the importance of these compounds in the industrial environment. Therefore, in this study, the diffusion step and diffusion coefficient of the lithium metaborate dihydrate compound at $45^{\circ} \mathrm{C}, 50^{\circ} \mathrm{C}$ and $60^{\circ} \mathrm{C}$ temperatures were determined by crystallization method. The diaphragm cell technique was used to determine the diffusion coefficient. It was also found that the diffusion coefficient at $45^{\circ} \mathrm{C}$ is higher than at $50^{\circ} \mathrm{C}$ and $60^{\circ} \mathrm{C}$. Therefore, to investigate this behavior at $45^{\circ} \mathrm{C}$, the viscosity values at different saturation temperatures were measured and the diffusion coefficients were calculated considering this equality.
\end{abstract}

Keywords: Lithium Metaborate Dihydrate, Diffusion, Crystallization, Diaphragm Cell.

\section{Giriş}

Henüz hakkında sodyum bileşikleri kadar araştırma yapılmamış ticari bor bileşiklerinden bazıları da lityum boratlardır. Lityum boratların en önemlileri lityum 1:2 boratlar (lityum tetraborat trihidrat, $\mathrm{Li}_{2} \mathrm{~B}_{4} \mathrm{O}_{7} .3 \mathrm{H}_{2} \mathrm{O}$ ), lityum 1:1 boratlardır (lityum metaborat oktahidrat, $\mathrm{LiBO}_{2} .8 \mathrm{H}_{2} \mathrm{O}$ )' tır. $\mathrm{Bu}$ çalışmada önemli lityum borat bileşiklerinden olan lityum metaborat dihidratın (difüzyon sınır tabaka kalınlığının bulunması) difüzyon katsayısının belirlenmesi amaçlanmıştır. Akışkanlar için en önemli özelliklerden biri difüzyon katsayısıdır. Akışkanlar mekaniği ve kütle transferi işlemlerinde difüzyon katsayısının bilinmesi tasarımlarında kolaylık sağlar. Bu deney düzeneğinde ise sıvı çözeltilerin sıvı içinde ve gazların durgun gaz içinde difüzyonu incelenecektir. Bu amaçla aşağıda kısaca verilen bilgilere gereksinim vardır. Durgun bir akışkan içinde konsantrasyon farkı ile kütle transferinin olması difüzyon olayı ile açıklanabilir. Suyla dolu bir bardağa mürekkep damlatıldığında, mürekkebin mavi renginin yavaş yavaş tüm suya dağıldığı ve sonunda üniform bir karışım elde edildiği bilinen bir gerçektir. Sıvı çözeltilerin pek çoğu için deneysel difüzyon katsayıları çeşitli kaynaklardan bulunabilir [1,2]. Kristalizasyon prosesi kullanılarak çok faklı maddelerin endüstriyel olarak üretimi gerçekleşmektedir. Kristalizasyon polimer üretiminde [3-5], moleküler cam üretiminde[6], vitamin üretiminde [7] ve birçok

\footnotetext{
* Sorumlu yazar: saitizgi@siirt.edu.tr

Geliş Tarihi: 13.04.2018, Kabul Tarihi: 05.10.2018
} 
inorganik tuzun üretiminde [8-12] yaygın olarak kullanılmaktadır [13-15]. Fakat kristalizasyon işlemini tek başına değerlendirmek oldukça basit gibi görünse de herhangi bir maddenin kristallenmesi için aşırı doygunluk, nükleasyon ve kristal büyümesinin gerçekleşmesi gerekmektedir. Bu nedenle kristalizasyon ile ilgili yapılan çalışmalar da metastabil bölge çalışmaları, kristal büyütme çalışmaları, endüstriyel üretim çalışmaları ve safsızlıkların etkilerinin incelendiği çalışmalar olarak sınıflandırabiliriz. Son zamanlarda kristalizasyon çalışmaları ile ilgili kristallerin anlık görüntüsünün alınması ve kristalleri çözelti ortamında sınıflandırabilen sistem olan FBRM ile ilgili çalışmalar yapılmıştır[16]. Lityum metaborat dihidratın katı haldeki kristal yapısı $\mathrm{LiB}(\mathrm{OH})_{4}$ şeklinde olup, sodyum metaboratın yapısıyla benzerlik göstermektedir [17]. Lityum metaborat dihidrat ortorombik yapıda kristalleşmekte, kristal yoğunluğu $1,825 \mathrm{gr} / \mathrm{ml}$ ve $36,9{ }^{\circ} \mathrm{C}$ 'nin altındaki sıcaklıklarda kendi çözeltisinde lityum metaborat octahidrat $\left(\mathrm{LiBO}_{2} 8 \mathrm{H}_{2} \mathrm{O}\right)$ olarak kristallenmektedir. Lityum metaborat dihidratın çözelti ortamında kristalizasyon prosesi kullanılarak endüstriyel üretime yönelik literatürsel bir çalışmaya rastlanılmamıştır. İnorganik tuzların üretiminde kristalizasyon ile ilgili çok sayıda çalışma mevcut olup bunların hepsinin verilmesi mümkün değil bu nedenle inorganik bor tuzlarının kristalizasyonu ile ilgili yapılan birkaç çalışmayı verecek olursak bize lityum metaborat dihidratın kristalizasyonu hakkında da bir yaklaşım sağlamış olur.

Bu çalışmanın amacı, endüstride birçok kullanım alanı bulan ve uygulama alanlarına yönelik çok sayıda patent alınmış olan bu iki bor bileşiğin üretimi hakkında literatürde fazla bilgi bulunmamaktadır. Bu çalışma lityum metaborat dihidratın üretim şartlarının belirlenmesinin ilk adımı olan difüzyon katsayısının belirlenmesi hedeflenmiştir. Aynı zamanda literatürdeki boşluğun doldurulması hedeflenmektedir. Reaksiyon aşağıdaki gibi borik asit ve lityum hidroksitin reaksiyonu sonucu oluşmaktadır.

$$
\mathrm{H}_{3} \mathrm{BO}_{3}+\mathrm{LiOH} \rightarrow \mathrm{LiBO}_{2} \cdot 2 \mathrm{H}_{2} \mathrm{O}
$$

Kısaca bu kadar yaygın kullanım alanına sahip bu bor bileşiklerinin üretim yöntemleri ve şartları hakkında literatürdeki bilgiler ne yazık ki gizli tutulmaktadır. Bu nedenle dünya bor rezervlerinin yaklaşı \% 65 ini elinde bulunduran ülkemiz için ticari değeri olan Lityum metaborat dihitratta' in üretim şartlarının ve yeni yöntemlerin belirlenmiş olması oldukça önemlidir.

\section{Materyal ve Metot}

Deneysel çalışmalarda kullanılan maddelerin difüzyon katsayısı belirlemek için birçok araştırmacı tarafından diyafram-hücre metodu kullanıldı [18-20]. Difüzyon katsayısını diyafram metot ile belirlemek için öncelikle kullanılan hücrenin, hücre sabitinin belirlenmesi gerekiyor. Diyafram hücre metodunda, diyafram hücrenin integral difüzyon katsayısı aşağıdaki gibi ifade edilmektedir [21].

$$
\bar{D}=-\frac{1}{\beta t} \operatorname{Ln}\left[\frac{C_{1}-C_{2}}{C_{3}-C_{4}}\right]
$$

2.1 nolu eşitlikten geçen $\bar{D}$, diyafram hücrenin integral difüzyon katsayısı, $\beta$ ise hücre sabitini göstermekte olup, genellikle potasyum klorür gibi difüzyon katsayısı bilinen maddeler kullanılarak belirlenir. Literatürde hücrenin karıştırma hızı için farklı değerler kullanılmış olmakla birlikte [18], 25 rpm in üstündeki bir karıştırma hızının yeterli olduğunu ifade etmiştir. Bu çalışmada hücrenin üst bölmesinde iletkenliğin zamanla değişimi ölçülerek konsantrasyon değişimi belirlenmiştir.

Eşitlik 2.1'e göre önce kendi sistemimizde $0.5 \mathrm{~N} \mathrm{KCI} \mathrm{çözeltisi} \mathrm{kullanılarak} \mathrm{zamana} \mathrm{bağlı} \mathrm{olarak}$ elde edilen hücredeki iki bölme arasındaki konsantrasyon değişimi için eşitlik $\operatorname{Ln}\left[\frac{C_{1}-C_{2}}{C_{3}-C_{4}}\right]$ karşın zaman grafiği çizildiğinde elde edilen doğrunun eğiminde potasyum klorürün diafram hücre integral difüzyon katsayısı kullanılarak hücre sabiti bulunur. Potasyum klorür maddesi baz alınarak, buradan elde edilen hücre sabiti kullanılmıştır. $\operatorname{Ln}\left[\frac{C_{1}-C_{2}}{C_{3}-C_{4}}\right]$ karşın zaman grafiği çizildiğinde elde edilen 
eğimde her bir başlangıç konsantrasyon için diyafram hücrenin integral difüzyon katsayısı belirlenir. Fakat hücrenin üst kısmında başlangıçta lityum metaborat dihidrat konsantrasyonu sıfır olduğunda, sıfır ile C konsantrasyonu arasında ortalama difüzyonu katsayısını, D'yi tanımlayan yeni bir terim tanımlanır buda $\bar{D}^{o}$ olup[21, 22], aşağıdaki gibi tanımlanır.

$\bar{D}^{o}\left(c_{1}^{m}\right)=\bar{D}-\left(c_{u}^{m} / c_{1}^{m}\right)\left(\bar{D}-\bar{D}^{o}\left(c_{u}^{m}\right)\right)$

Buradan geçen $c_{1}^{m}=\left(c_{1}+c_{3}\right) / 2$ ve $c_{u}^{m}=\left(c_{2}+c_{4}\right) / 2$ şeklinde tanımlanır ve bu eşitlik bize ortalama bir konsantrasyon için integral difüzyon katsayısının hesaplanmasına olanak tanır.

Diferansiyel difüzyon katsayısı ile integral difüzyon katsayısı arasında aşağıdaki gibi bir eşitlik tanımlanmıştır.

$D=\bar{D}^{o}+c\left(d \bar{D}^{o} / d c\right)$

Difüzyon çalışmalarında kullanılan sistem Şekil 2.1. de verilmiştir. Şekilde görüleceği difüzyon sistemi iki kısımda oluşmakta, bunlardan alt kısımda istenen konsantrasyonda lityum metaborat dihidrat konulmakta ve üst kısımda ise saf su konulmaktadır. Arada ise geçirgen bir zar bulunmakta ve her iki kısımda sıcaklık dengesi bir kryostat ile sağlanmaktadır. Sistemin sıcaklığ 1 üst hücreye konulan bir Pt100 termoelemanı $0.01{ }^{\circ} \mathrm{C}$ hassasiyetle kontrol edilmektedir. Deneyde üst hücrede bulunan bir iletkenlik ölçme cihazı ile konsantrasyon değişimi ölçülmektedir. Deneysel çalışmalara başlamadan önce iletken ölçüm cihazı çeşitli konsantrasyonlara sahip lityum metaborat dihidrat çözeltilerinin iletkenliği ölçülerek, konsantrasyon iletkenlik fonksiyonu, $\mathrm{C}=\mathrm{f}(\lambda)$ farklı sıcaklıklar için çıkarılmıştır. Daha sonra deneysel çalışmalarda zamana bağlı olarak ölçülen iletkenlik değerlerinde yararlanılarak konsantrasyona geçilmiştir.

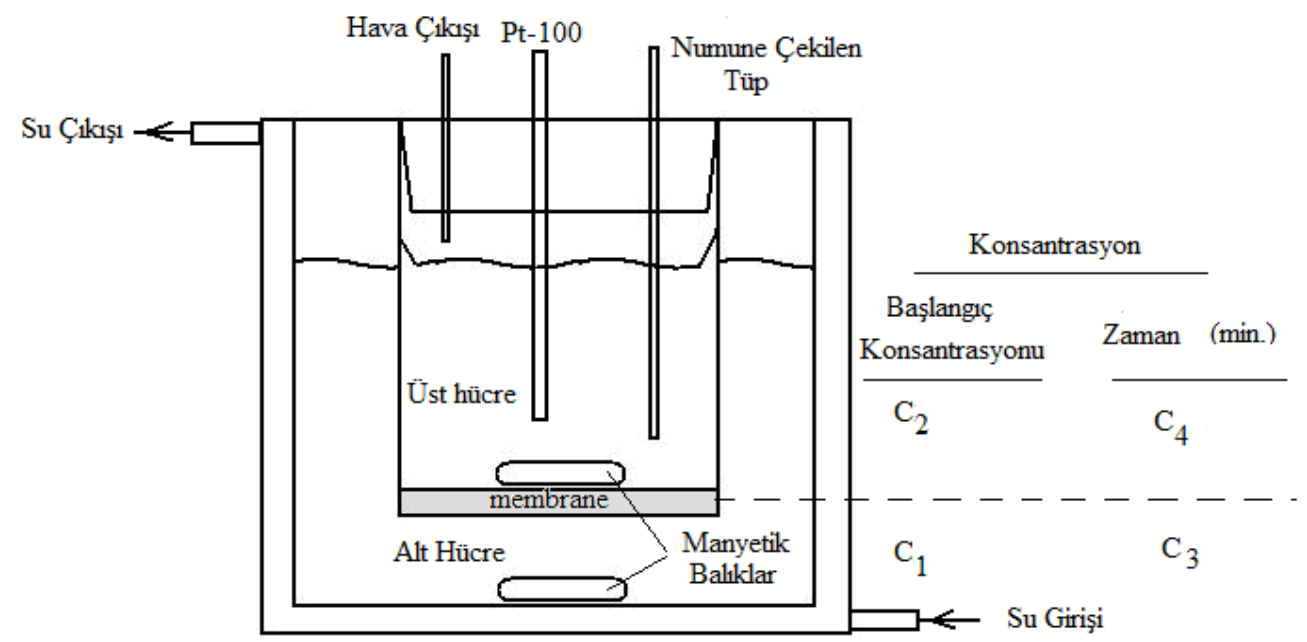

Şekil 2.1. Difüzyon çalışmalarında kullanılan sistem

Yukarıdaki şekilde ifade edildiği gibi alt hücreye lityum metaborat dihidratın farklı başlangıç konsantrasyonları (0.05-1.6 mol/1 arasındaki konsantrasyonlarda en 5 farklı konsantrasyon alınmıştır) ve üst hücreye saf su konularak deneylere başlanılmıştır. $45{ }^{\circ} \mathrm{C}, 50{ }^{\circ} \mathrm{C}$ ve $60{ }^{\circ} \mathrm{C}$ Üç farklı sıcaklık için aynı konsantrasyon aralığında değerler alınarak başlanılmış ve her deneyde üst hücrenin iletkenliği belirli aralıklarla 4 saat boyunca ölçülmüss ve daha sonra elde edilen iletkenlik değerleri konsantrasyonu çevrilmiştir. 


\section{Bulgular ve Tartışma}

Elde edilen sonuçlar kullanılarak diyafram hücrenin integral difüzyon katsayısı eşitlik 1 kullanılarak bulunmuştur. Bulunan bu integral difüzyon katsayısının alt hücredeki lityum metaborat dihidratın başlangıç konsantrasyonu ile değişimi Şekil 3.1.' de verilmiştir. Şekil 3.1.'de görüleceği gibi diyafram hücresinin integral difüzyon katsayıs1 $50{ }^{\circ} \mathrm{C}$ 'de en düşük $45^{\circ} \mathrm{C}$ 'de ise en yüksek değerleri almaktadır. Konsantrasyon değişimi ile bütün sıcaklıklardaki davranış birbirine paralellik arz etmektedir. Fakat 45 ${ }^{0} \mathrm{C}$ deki integral difüzyon katsayıların $50{ }^{\circ} \mathrm{C}$ ve $60{ }^{\circ} \mathrm{C}$ 'ye nazaran daha yüksek olması beklenen bir durum olmayıp farklı bir davranış şeklidir. Aynı deneyler bir kaç kere tekrarlanmasına rağmen davranış şekli değişmemiştir. Bu durumun açıklanması için farklı sıcaklıklardaki doygun çözeltilerin yoğunluk ve vizkozite değerlerine bakılması ve ona göre yorum yapılması yerinde olacaktır.

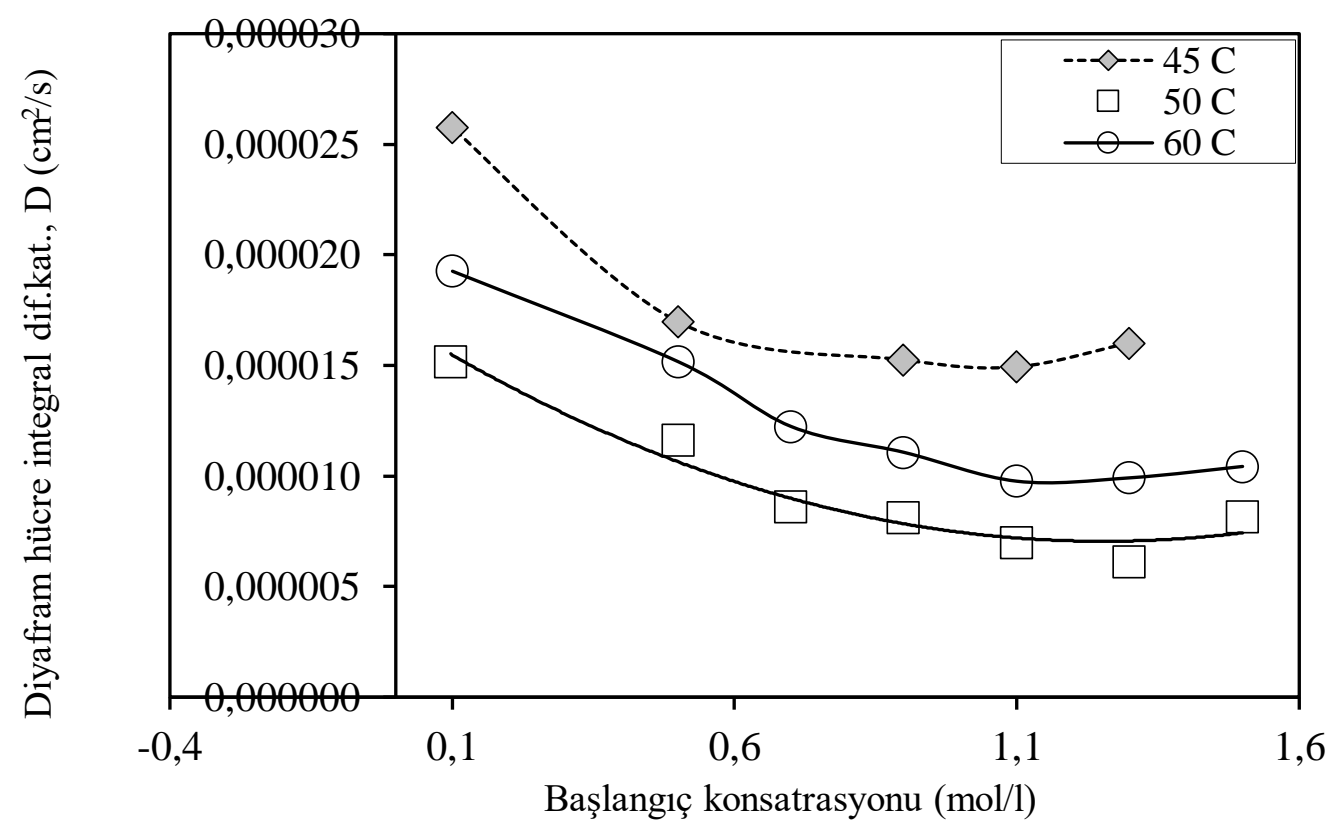

Şekil 3.1. Diyafram hücrenin integral difüzyon katsayısının başlangıç konsantrasyonu ve sıcaklıkla değişimi

Şekil 4.1'in ilk yarısı üst hücredeki difüzyonu temsil ederken diğer kısmı ise daha konsantre olan alt hücredeki integral difüzyon katsayısını temsil etmektedir. Eşitlik 2.2'te geçen alt hücre integral difüzyon katsayısı $\bar{D}^{o}\left(c_{1}^{m}\right)$ ve üst hücre integral difüzyon katsayısını $\bar{D}^{o}\left(c_{u}^{m}\right)$ bulmak için aşağıdaki gibi bir yol izlendi. Aynı yöntem literatürde farklı şekillerde birçok araştırmacı tarafından kullanıldı [168-172].

- Öncelikle $\bar{D}$ ' 1 farklı lityum metaborat dihidrat başlangıç konsantrasyonlarına bağlayan bir polinom denklem bağıntısı bulundu.

- Yukarıda buluna eşitliğe $c_{u}^{m}$ değerleri konularak $\left.\bar{D}^{o}\left(c_{u}^{m}\right)\right)$ 'değerleri bulundu. Bu değerler 2'nolu eşitlikte yerine konularak $\bar{D}^{o}\left(c_{1}^{m}\right)$ değerleri bulundu

- Bulunan bu $\bar{D}^{o}\left(c_{1}^{m}\right)$ değerleri ile $c_{1}^{m}$ değerleri arasında yeni bir polinom denklemi bulundu. Bulunan bu denklemde $c_{u}^{m}$ değerleri tekrar konularak yeni $\left.\bar{D}^{o}\left(c_{u}^{m}\right)\right)$ değerleri bulundu.

- Tekrar yeni bulunan bu $\left.\bar{D}^{o}\left(c_{u}^{m}\right)\right)$ 'değerleri yerine konularak 2 nolu eşitlikte $\bar{D}^{o}\left(c_{1}^{m}\right)$ değerleri bulundu ve bu işlem ardışı iki $\bar{D}^{o}\left(c_{1}^{m}\right)$ değerleri eşit olana kadar devam edildi. Şekil 3.2.'te art arda yapılan üç yaklaşım için alt hücrenin integral difüzyon katsayısının başlangıç konsantrasyonu ile değişimi verişmiştir. 
Şekil 3.2.'de görüleceği gibi $\bar{D}^{o}\left(c_{1}^{m}\right)$ 'nin 1. yaklaşım ve 3. yaklaşım arasında oldukça fark olmasına rağmen 2. ve 3. yaklaşımlar arasında fazla farkın olmadığı dolayısıyla işlemin bundan sonra devam edilse bile hemen hemen aynı değerleri alacağını göstermektedir.

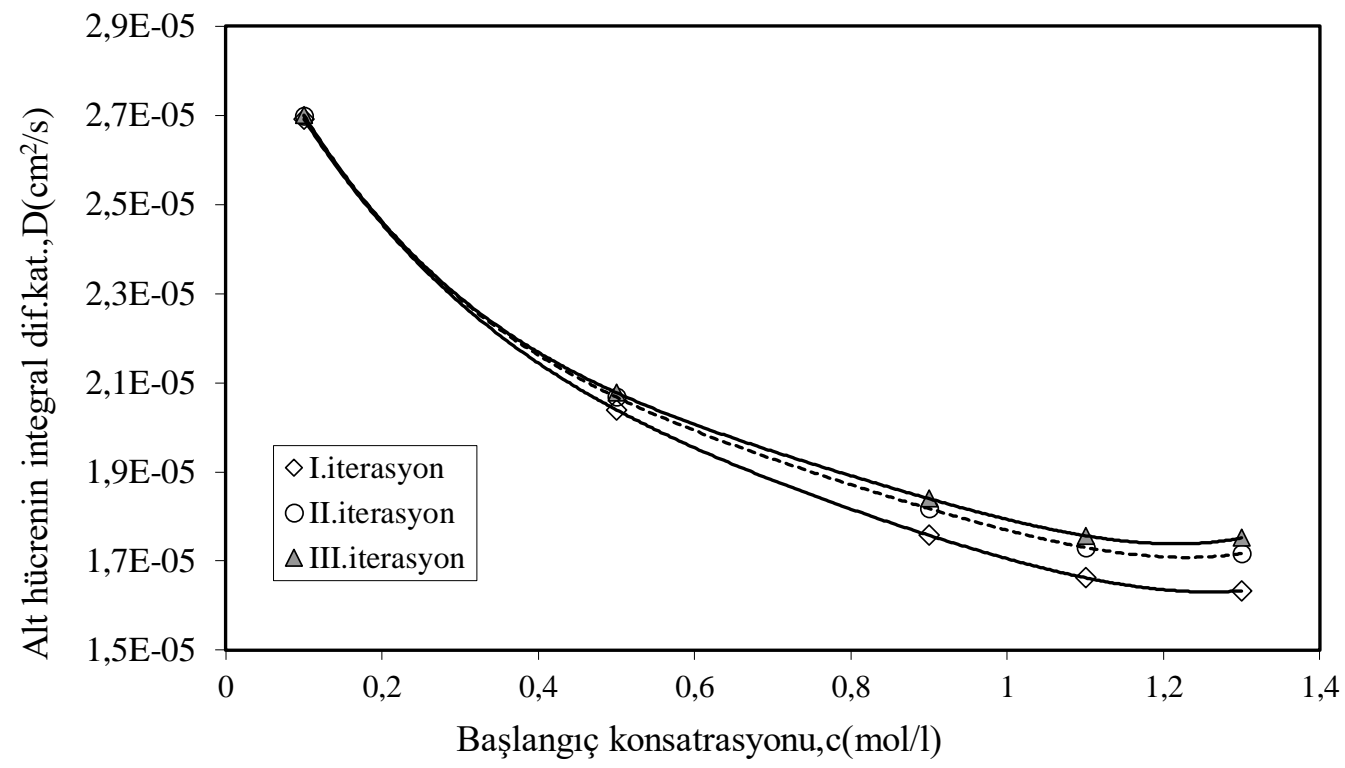

Şekil 3.2. $\bar{D}^{o}\left(c_{1}^{m}\right)$ 'nin başlangıç konsantrasyonu ile değişimi $\left(45^{0} \mathrm{C}\right.$ için verilmiştir.)

Deneysel çalışmaların yapıldığı her bir sıcaklık için yukarıdaki yaklaşım sağlandıktan sonra gerçek difüzyon katsayısı olan diferansiyel difüzyon katsayısını bulmak için eşitlik 3'kullanıldı. Her bir sıcaklıktaki diferansiyel difüzyon katsayılarının farklı başlangıç konsantrasyonları ile değişimi Şekil 3.3.'te verilmiştir. Şeklin davranışı yani sıcaklıkla değişimi tıpkı integral difüzyon katsayısında olduğu gibi $45{ }^{\circ} \mathrm{C}$ hariç diğer sıcaklıklarda $50{ }^{\circ} \mathrm{C}$ ve $60{ }^{\circ} \mathrm{C}^{\prime}$ lerde difüzyon katsayısı sıcaklıkla artmaktadır. Fakat en yüksek difüzyon değerleri $45^{\circ} \mathrm{C}^{\prime}$ de elde edilmektedir.

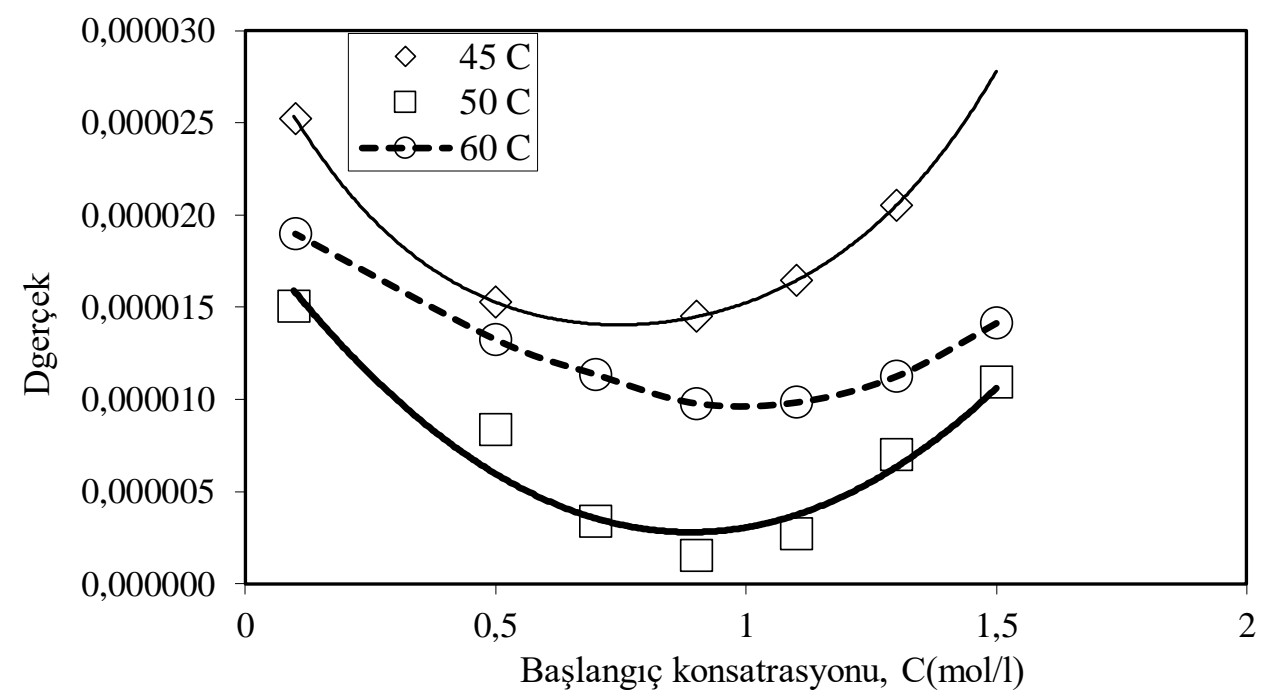

Şekil 3.3. Farklı sıcaklıklar için diferansiyel difüzyon katsayısının başlangıç konsantrasyonu ile değişimi

Sonuç olarak difüzyon ile ilgili yaptığımız çalışmalarda elde etiğimiz sonuçlar her ne kadar yukarıda verilmiş ise özellikle $45{ }^{\circ} \mathrm{C}$ 'deki davranış beklenen bir davranış olmadığını ifade etik. $\mathrm{Bu}$ 
davranışın bilimsel açıklanması için lityum metaborat dihidrat çözeltisinin 45,50 ve $60{ }^{\circ} \mathrm{C}^{\prime}$ lerdeki yoğunluk ve viskozite değerleri sirasiyla Anton Paar DMA 5000 M ve Brookfield DV-II+ Pro cihazlarında ölçülmüş elde edilen değerler Tablo 2' de verilmiştir.

Tablo 1. Lityum metaborat dihidratın farklı sıcaklıklardaki doygun çözeltilerinin viskozite ve yoğunluk değerleri

\begin{tabular}{|c|c|c|}
\hline $\mathrm{T}$ & Vizkozite $(\mathrm{cP})$ & Yoğunluk $(\mathrm{g} / \mathrm{cm} 3)$ \\
\hline 45 & 0,52 & 1,0833 \\
\hline 50 & 0,61 & 1,0794 \\
\hline 60 & 0,66 & 1,0769 \\
\hline
\end{tabular}

Tablo 1'de verilen değerler kullanılarak, literatürde yayın olarak kullanılan Wilke ve Chang eşitliği[23];

$$
\mathrm{D}=7,4 * 10-8 \frac{\left({ }^{\prime} \mathrm{YM}\right) \mathrm{T}^{0,5}}{\grave{\eta} \mathrm{v}^{0,6}}
$$

Denkleminden yola çıkılarak Şekil 3.4 elde edilmiştir.

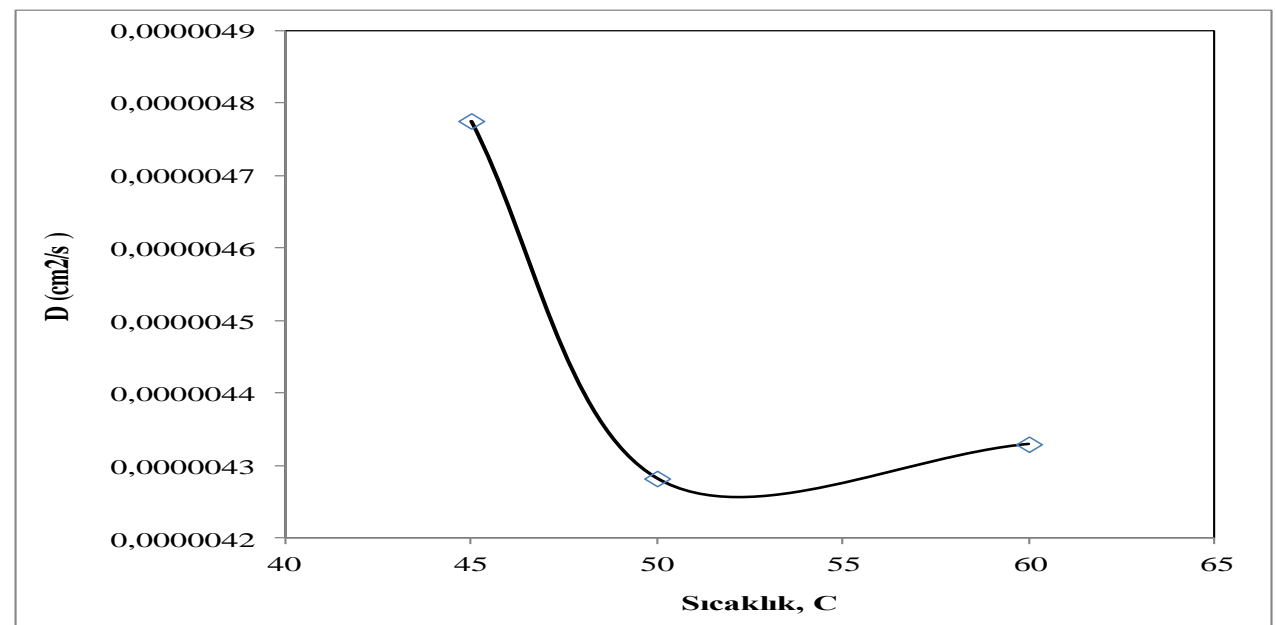

Şekil 3.4. Wilke ve Chang eşitliğine göre diffüzyon katsayıların $45{ }^{\circ} \mathrm{C}, 50{ }^{\circ} \mathrm{C}$ ve $60{ }^{\circ} \mathrm{C}$ 'lerde doygun çözeltilerde sıcaklıkla değişimi

Şekil 3.4'te görüleceği gibi difüzyon katsayısının sıcaklıkla değişim davranışı Şekil 4.3'teki davranış1 desteklemektedir. Deneysel olarak elde edilen verilerde sistemde kaynaklanan bir hata ihtimali olma olasılığı hemen hemen yok gibidir zira elde edilen sonuçlar tekrarlanan sonuçlardır. Literatürde de deneysel sonuçlar ile Wilke-Chang eşitliğinde elde edilen sonuçlardan yüksek hata yüzdeli sonuçlara rastlamak mümkün olup bunlardan birkaç örnek verecek olursak; anilin etanol için \% 69, sinnamik asittoluen için \% 59.4, asetik asit-karbontetraklorür için \%24.2 hata yüzdeleri elde edilmiş [24] aynı şekilde seçilmiş başka bir ikili sıvı sistemlerinin (siklopentanol-asetik asit, sikloheksanol-asetik asit ve metilsikloheksanol-asetik asit) difüzyon katsayılarının tayininde diyafram hücresi tekniği kullanılmış olup bu sistemde Wilke-Chang yöntem ile deneysel yöntem arasında bulunan sonuçlarda \%25-80 arasında hatta tespit edilmiştir [25]. Şunu da ifade etmek yerinde olur burada Wilke-Chang eşitliği kullanılmasındaki amaç diyafram hücre yöntemi ile elde edilen sonuçları kıyaslamak için değil diyafram hücre yönteminde elde edilen davranışı doğrulamaktır. Zira diyafram hücre metodunun formülasyonunda viskozite ve yoğunluğun etkinliği görülmemektedir. Fakat yoğunluk ve viskozitenin difüzyon katsayısı üzerindeki etkinliği Wilke-Chang eşitliğindeki formülasyonunda verilmiş̧ir. Bu nedenle deneysel olarak diyafram hücre yöntemi ile elde edilen sonuçlar başka çalışmalarda kullanılması yerinde olacaktır. 


\section{Sonuç ve Öneriler}

Lityum Metaborat Dihidrat'ın kristalizasyonunda difüzyon katsayısını belirlemek için diyafram-hücre metodu kullanılmıştır. $45^{\circ} \mathrm{C}, 50{ }^{\circ} \mathrm{C}$ ve $60{ }^{\circ} \mathrm{C}$ üç farklı sıcaklık değeri için aynı konsantrasyon aralığında çeşitli değerler alınarak başlanılmış ve her deneyde üst hücrenin iletkenliği belirli aralıklarla 4 saat boyunca ölçülmüş ve daha sonra elde edilen iletkenlik değerleri konsantrasyona dönüştürülmüsstür. Elde edilen sonuçlar kullanılarak diyafram hücrenin integral difüzyon katsayısı Denklem 2.1 kullanılarak bulunmuştur. Her bir sıcaklıktaki diferansiyel difüzyon katsayılarının farklı başlangıç konsantrasyonları ile değişimi Şekil 3.3'te verilmiştir. Şeklin davranışı yani sıcaklıkla değişimi tıpkı integral difüzyon katsayısında olduğu gibi $45{ }^{\circ} \mathrm{C}$ hariç, diğer sıcaklıklarda $50{ }^{\circ} \mathrm{C}$ ve $60{ }^{\circ} \mathrm{C}^{\prime} l e r d e$ difüzyon katsayısı sıcaklıkla artmaktadır. Fakat en yüksek difüzyon değerleri $45^{\circ} \mathrm{C}^{\prime}$ de elde edilmiştir. Dolayısıyla $45{ }^{\circ} \mathrm{C}$ deki bu davranışı aydınlatmak için farklı doygunluk sıcaklıklarındaki viskozite değerleri ölçülerek difüzyon katsayıları bu eşitliği göre hesaplanmış ve yorumlanmıştır.

\section{Teşekkür}

Bu çalışma 111 M 299 no'lu TÜBİTAK projesi kapsamında desteklenmiştir.

\section{Kaynaklar}

[1] Prosini P., Lisi M., Zane D., Pasquali M. 2002. Determination of the chemical diffusion coefficient of lithium in LiFePO4. Solid State Ionics, 148 (1): 45-51.

[2] Ding N., Xu J., Yao Y.X., Fang X., Chen C.H. 2009. Determination of the diffusion coefficient of lithium ions in nano-Si. Solid State Ionics, 180 (2-3): 222-225.

[3] Liu P., Hu A., Wang S., Shi M., Ye G., Xu J., 2011. Evaluation of nonisothermal crystallization kinetic models for linear poly (phenylene sulfide). Journal of Applied Polymer Science, 121 (1): $14-20$

[4] Kim B.C., Maeda K., Kim Y.H. 2011. Monitoring nonisothermal crystallization of thermoplastic polymers using a quartz crystal resonator. Journal of Applied Polymer Science, 120 (6): 3370-3380.

[5] Sencadas V., Martins P., Pitaes A., Benelmekki M. 2011. Influence of ferrite nanoparticle type and content on the crystallization kinetics and electroactive phase nucleation of poly (vinylidene fluoride). Langmuir, 27 (11): 7241-7249.

[6] Deb B., Ghosh A. 2011. Crystallization kinetics in selenium molybdate molecular glasses. EPL (Europhysics Letters), 95 (2): 26002.

[7] Wierzbowska B., Hutnik N., Piotrowski K., Matynia A. 2011. Continuous mass crystallization of vitamin C in L (+)-ascorbic acid- ethanol- water system: Size-independent growth kinetic model approach. Crystal Growth \& Design, 11 (5): 1557-1565.

[8] Urréjola S., Sánchez A., Hervello M. 2011. Solubilities of Sodium, Potassium, and Copper (II) Sulfates in Ethanol- Water Solutions. Journal of Chemical \& Engineering Data, 56 (5): 2687-2691.

[9] Sayan P., Sargut S.T., Kiran B. 2011. Effect of ultrasonic irradiation on crystallization kinetics of potassium dihydrogen phosphate. Ultrasonics sonochemistry, 18 (3): 795-800.

[10] Kobari M., Kubota N, Hirasawa I. 2011. Computer simulation of metastable zone width for unseeded potassium sulfate aqueous solution. Journal of Crystal Growth, 317 (1): 64-69.

[11] Buchfink R., Schmidt C., Ulrich J., 2011. Fe3+ as an example of the effect of trivalent additives on the crystallization of inorganic compounds, here ammonium sulfate. CrystEngComm, 13 (4): 11181122.

[12] Sangwal K. 2011. Some features of metastable zone width of various systems determined by polythermal method. CrystEngComm, 13 (2): 489-501.

[13] Song X., Zhang M., Wang J., Li P., Yu J. 2010. Optimization design for DTB industrial crystallizer of potassium chloride. Industrial \& Engineering Chemistry Research, 49 (21): 10297-10302.

[14] Kobari M., Kubota N., Hirasawa I. 2010. Simulation of metastable zone width and induction time for a seeded aqueous solution of potassium sulfate. Journal of Crystal Growth, 312 (19): 27342739. 
[15] Cui P., Zhang F.L., Guo Z.C. 2010. Gypsum crystallization and potassium chloride regeneration by reaction of calcium chloride solution with potassium sulfate solution or solid. Transactions of Nonferrous Metals Society of China, 20 (4): 712-720.

[16] Kutluay S., Şahin O., Ceyhan A., İzgi M.S. 2017. Design and optimization of production parameters for boric acid crystals with the crystallization process in an MSMPR crystallizer using FBRM ${ }^{\circledR}$ and PVM ${ }^{\circledR}$ technologies. Journal of Crystal Growth, 467: 172-180.

[17] Schubert, D.M. 2000. Boric oxide, boric acid, and borates. Ullmann's encyclopedia of industrial chemistry, 4.

[18] Solutions E., Robinson R.A., Stokes R.H. 1959. Butterworths: London.

[19] Gordon A. 1945. The diaphragm cell method of measuring diffusion. Annals of the New York Academy of Sciences, 46 (5): 285-308.

[20] Diao K., Zhang L., Zhao Y. 2017. Measurement of tortuosity of porous $\mathrm{Cu}$ using a diffusion diaphragm cell. Measurement, 110: 335-338.

[21] Stokes R. 1950. An improved diaphragm-cell for diffusion studies, and some tests of the method. Journal of the American Chemical Society, 72 (2): 763-767.

[22] Volmer M. 1939. Kinetic der Phasenbildung; Steinkopff: Leipzig, Germany, There is no corresponding record for this reference.

[23] Wilke C., Chang P. 1955. Correlation of diffusion coefficients in dilute solutions. AIChE Journal, 1 (2): 264-270.

[24] Reddy K., Doraiswamy L. 1967. Estimating liquid diffusivity. Industrial \& Engineering Chemistry Fundamentals, 6 (1): 77-79.

[25] İnce E. 2001. İkili Sıvı Sistemlerinin Difüzyon Katsayılarının Tayini. Mühendislik Bilimleri Dergisi, 7 (3): 409-413. 